ACTA UNIVERSITATIS NICOLA I C P ER NICI

EKONOMIA XLIII nr 1 (2012)

\title{
TRANSMISJA KRYZYSU ZAUFANIA NA POLSKI RYNEK MIĘDZYBANKOWY
}

Z a r y s t r e ś c i. Były przewodniczący Rady Gubernatorów Rezerw Federalnych Alan Greenspan określił niedawno spread LIBOR-OIS, rozumiany jako różnica pomiędzy stopą LIBOR oraz stawką OIS o tym samym terminie zapadalności, miarą obecnego na rynku międzybankowym strachu przed niewypłacalnością innych banków. Badając zależności pomiędzy spreadami dla strefy euro, Stanów Zjednoczonych oraz Polski określamy moment transmisji kryzysu na poszczególne rynki oraz usiłujemy określić kierunki jego przenoszenia. Przeprowadzoną analizę oparto na wynikach otrzymanych na podstawie dopasowanych wielowymiarowych modeli parametrycznych. Za ich pomocą wykazaliśmy silne przenikanie impulsów pomiędzy Stanami Zjednoczonymi i strefą euro oraz brak bezpośredniej zależności spreadu dla Polski od któregokolwiek z pozostałych spreadów.

S ło w a k l u c z o w e : korelacja warunkowa, funkcja odpowiedzi na impuls, przyczynowość w sensie Grangera, spread LIBOR-OIS.

\section{WSTĘP}

Skuteczne kontrolowanie inflacji w Stanach Zjednoczonych i Europie Zachodniej przełożyło się na znaczącą obniżkę stóp procentowych. Ta zaś

* Adres do korespondencji: Agata Kliber, Uniwersytet Ekonomiczny w Poznaniu, WIiGE, Al. Niepodległości 10, 61-875 Poznań, e-mail: agata.kliber@ue.poznan.pl; Piotr Płuciennik, Uniwersytet im. Adama Mickiewicza, WMiE, ul. Ulmutowska 87, 61-614 Poznań, e-mail: pplucien@amu.edu.pl. Praca naukowa finansowana ze środków budżetowych na naukę w latach 2010-2013 jako projekt badawczy N N111 035139.

(C) 2012 Wydawnictwo Naukowe Uniwersytetu Mikołaja Kopernika. All rights reserved. http://www.aunc.ekonomia.umk.pl 
przyczyniła się do powstania w ciagu ostatniej dekady ogromnych baniek kredytowych. Fala podwyżek stopy rezerw federalnych z poziomu $1 \% \mathrm{w}$ drugiej połowie 2003 roku do 5,25\% w ostatnim kwartale 2006 stała się główną przyczyną pęknięcia ogromnej bańki spekulacyjnej kredytów hipotecznych subprime. Silna przecena nieruchomości stała się nie tylko przyczyną kłopotów finansowych banków, które zmuszone były do sprzedaży zajętych hipotek po bardzo zaniżonych cenach, ale szybko przełożyła się na kłopoty innych sektorów gospodarki. Według raportów komitetu NBER odpowiedzialnego za datowanie cykli koniunkturalnych, recesja w Stanach Zjednoczonych rozpoczęła się już w IV kwartale 2007 roku. Z niewielkim opóźnieniem kryzys przeniósł się do strefy euro, w której kilka krajów borykało się dodatkowo z problemem zbyt dużego zadłużenia sektora publicznego ${ }^{1}$.

Skutki światowego kryzysu gospodarczego w początkowej fazie odczuły jedynie rynki kapitałowe. W połowie 2008 roku odwróceniu uległ trend aprecjacyjny wielu walut Europy Środkowo-Wschodniej, w tym złotego. W III i IV kwartale 2008 roku nastąpiło w Polsce znaczące obniżenie wskaźników koniunktury gospodarczej, przy znacznym spadku wykorzystania mocy produkcyjnych. W II połowie 2009 roku dynamika produktu krajowego zaczęła jednak powoli odrabiać straty, a Polska była jedynym krajem regionu, który zakończył najgorszy, 2009 rok z dodatnią dynamiką PKB. Jako przyczyny stosunkowo łagodnego przejścia Polski przez światowy kryzys finansowy wymienia się m.in.: przeprowadzoną uprzednio reformę podatkową, duży wzrost inwestycji publicznych w związku ze zbliżającą się organizacją Euro 2012, optymizm konsumentów i, jak na ironię, dużą deprecjację złotego. Ta ostatnia z jednej strony przyczyniła się do wzrostu zadłużenia zagranicznego i strat niektórych przedsiębiorstw z tytułu zawartych wcześniej transakcji opcyjnych, $z$ drugiej jednak strony polskie towary mogły być sprzedawane za granicę taniej bądź z niższą marżą. Sytuacja polskiego sektora bankowego na tle innych rynków również wyglądała całkiem dobrze. Polskie banki nie były w posiadaniu tzw. toksycznych papierów wartościowych, a głównym kanałem, przez który kryzys przeniknął do sektora bankowego, był kanał zaufania. Skutków kryzysu zaufania nie można lekceważyć, jednak inne uwarunkowania rozwoju kryzysu w Polsce (por. Narodowy Bank Polski, 2009) oraz fakt, że polska gospodarka

\footnotetext{
${ }^{1}$ O negatywnej ocenie ryzyka kredytowego długoterminowych obligacji Grecji, Hiszpanii, Włoch i Portugalii świadczą rosnące, począwszy od 2007 roku, spready pomiędzy ich rentownością a rentownością obligacji niemieckich o tym samym terminie zapadalności oraz rosnący koszt kontraktów CDS dla tych państw (por. Gibson, Hall, Tavlas, 2011). Warto dodać, że długoterminowe obligacje rządu federalnego Niemiec stanowią referencyjny papier wartościowy (tzw. benchmark) dla długoterminowych obligacji pozostałych państw członkowskich UE. Dlatego tak ważny jest stopień zróżnicowania pomiędzy nimi.
} 
w znacznie większym stopniu powiązana jest z gospodarką krajów strefy euro niż Stanów Zjednoczonych, skłania nas do postawienia dwóch hipotez, które w tej pracy udowadniamy. Pierwsza z nich mówi, że kryzys zaufania przenika na polski rynek międzybankowy ze znacznym opóźnieniem, a na jego rozwój wpływ mają inne czynniki niż w przypadku Stanów Zjednoczonych i strefy euro. Druga, że kryzys zaufania nie przeniknął do Polski bezpośrednio ze Stanów Zjednoczonych, ale za pośrednictwem strefy euro. Postawione hipotezy zweryfikujemy, stosując analizę spreadów pomiędzy 3-miesięcznymi stopami LIBOR a stawkami 3-miesięcznych kontraktów OIS (Overnight Interest Swap), które będziemy w skrócie nazywać spreadami LIBOR-OIS. Są one indykatorami nasilenia strachu przed niewypłacalnością kontrahenta na rynku międzybankowym (por. Sengupta, Yu, 2008; Thornton, 2009).

Spready LIBOR-OIS zyskały na popularności w ostatnich kilku latach i są wykorzystywane głównie do badania obecnej na rynkach międzybankowych awersji do ryzyka oraz wpływu poszczególnych wydarzeń na jej wielkość. In i in. (2008) przeanalizowali wpływ operacji TAF na spread LIBOR-OIS, dzięki czemu mogli ocenić, na ile operacje te przyczyniały się do poprawy sytuacji w sektorze bankowym. W raporcie European Central Bank (2008) przeprowadzono testy przyczynowości w sensie Grangera, celem zbadania zależności pomiędzy kryzysem zaufania w strefie euro, Stanach Zjednoczonych i Wielkiej Brytanii. W raporcie Bank of Japan (2008), celem lepszego poznania kierunków przenikania kryzysu, przeprowadzono analizę opartą na funkcjach odpowiedzi na impuls dla spreadów w odniesieniu do Stanów Zjednoczonych, strefy euro i Japonii. Soultanaeva i Strömqvist (2009) w podobny sposób określiły kierunki transmisji kryzysu zaufania do Szwecji.

Przeprowadzona w pracy analiza opiera się na wielowymiarowych modelach średniej i wariancji warunkowej. Zinterpretowano funkcje odpowiedzi na impuls w średniej i wariancji, a otrzymane wyniki dodatkowo potwierdzono przez testy przyczynowości w sensie Grangera.

W rozdziale pierwszym omawiamy wykorzystane w artykule dane 3-miesięczne spready LIBOR/WIBOR-OIS - objaśniając jednoczenie przyczyny ich wahań. W drugim rozdziale przeprowadzamy badanie ekonometryczne, mające na celu zweryfikowanie postawionych w artykule hipotez. $\mathrm{W}$ ostatnim, trzecim rozdziale formułujemy wypływające $\mathrm{z}$ badania wnioski.

\section{DANE}

Analizie poddane zostały 3-miesięczne spready LIBOR/WIBOR-OIS z okresu od stycznia 2006 do 24 września 2010 roku, których poziomy przed- 
stawione są na rysunku 1. Do sierpnia 2007 roku bliskie zeru spready dla Stanów Zjednoczonych, strefy euro i złotego nie wskazują na nic niepokojącego.

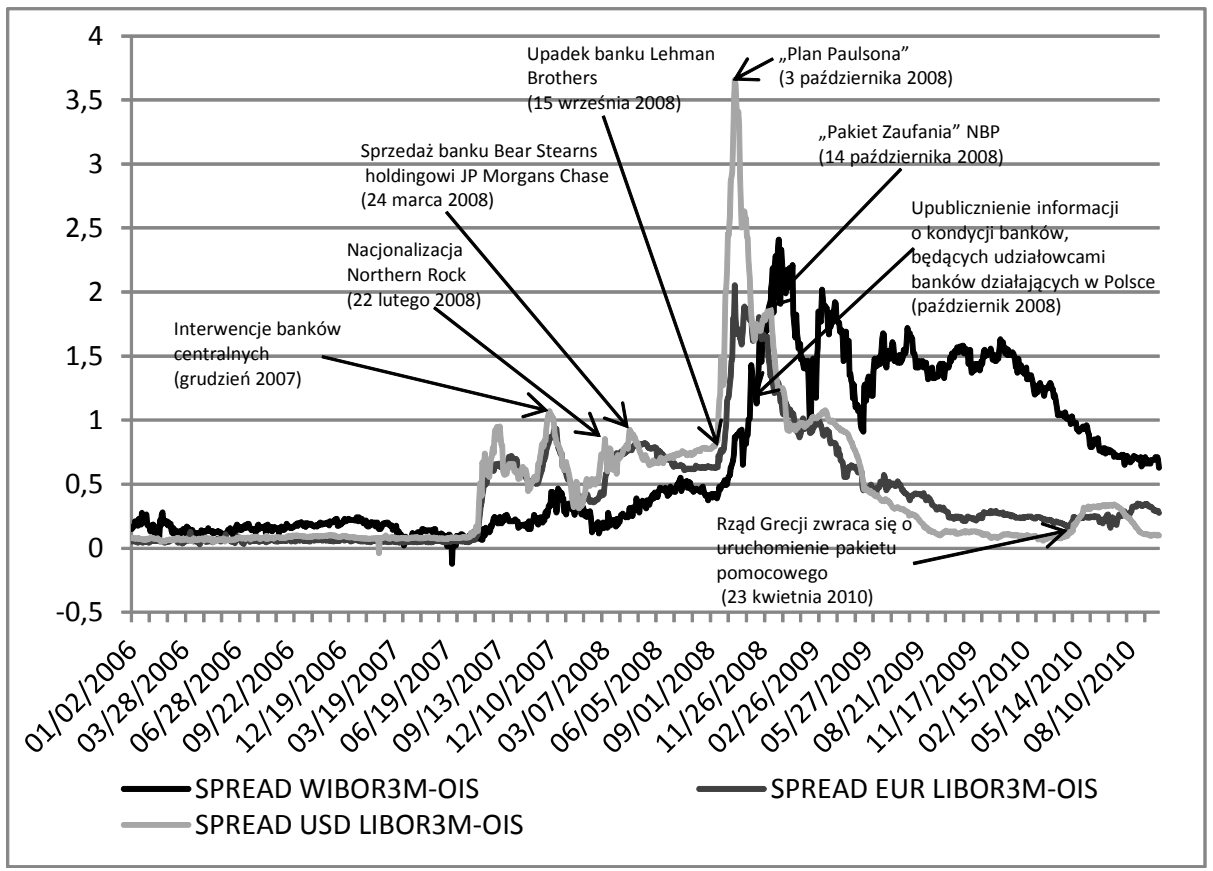

Rysunek 1. 3-miesięczne spready LIBOR-OIS dla Polski, strefy euro oraz Stanów Zjednoczonych

Źródło: obliczenia własne.

Sytuacja gwałtownie ulega zmianie w sierpniu 2007. Wówczas w Stanach Zjednoczonych, w związku z ogromną skalą udzielonych kredytów subprime, gwałtownie spada zaufanie do instytucji finansowych. Ponieważ amerykańskie papiery wartościowe powiązane $\mathrm{z}$ rynkiem nieruchomości sprzedawane były także za granica, kryzys zaufania bardzo szybko przenika na inne rynki, w tym do strefy euro. Wzrost spreadu jest obserwowalny także w Polsce, chociaż polskie instytucje finansowe nie kupowały tzw. toksycznych papierów wartościowych. Jest to typowy skutek efektu zarażania, o czym dodatkowo świadczy mała korelacja spreadów w tym okresie. Spready dla Stanów Zjednoczonych i strefy euro wykazują tendencję wzrostową aż do grudnia 2007, kiedy FED oraz inne banki centralne wprowadzają pakiety operacji mających na celu zasilenie sektora bankowego w płynność (szeroką ocenę skuteczności operacji zasilających można znaleźć w artykule Wu 2008). Spadek wartości spreadów 
jest jednak krótkofalowy i w lutym 2008 roku następuje ich ponowny wzrost po tym, jak borykający się od dłuższego czasu z problemami płynności piąty co do wielkości w Wielkiej Brytanii bank kredytowy Northern Rock staje na skraju bankructwa. Uzyskanie we wrześniu 2007 roku nadzwyczajnej linii kredytowej w wysokości 25 mld funtów w Banku Anglii jest negatywnym sygnałem dla klientów banku, którzy zaczynają wycofywać depozyty. Ostatecznie po dwóch nieudanych próbach sprzedaży 22 lutego bank zostaje znacjonalizowany.

Kolejny krótkofalowy spadek spreadów świadczy o tym, że rynek przyjął tę informację bardzo pozytywnie. Po dwóch tygodniach spready ponownie zaczynają rosnąć, co wiąże się tym razem z ryzykiem bankructwa banku Bear Stearns. W połowie marca 2008 roku akcje banku zaczynają szybko tracić na wartości. Ostatecznie bank zostaje przejęty przez JP Morgan Chase, które wykupuje w sumie 39\% udziałów. Informacja ta ponownie staje się pozytywnym sygnałem dla rynku, co ostatecznie staje się przyczyną spadków spreadów.

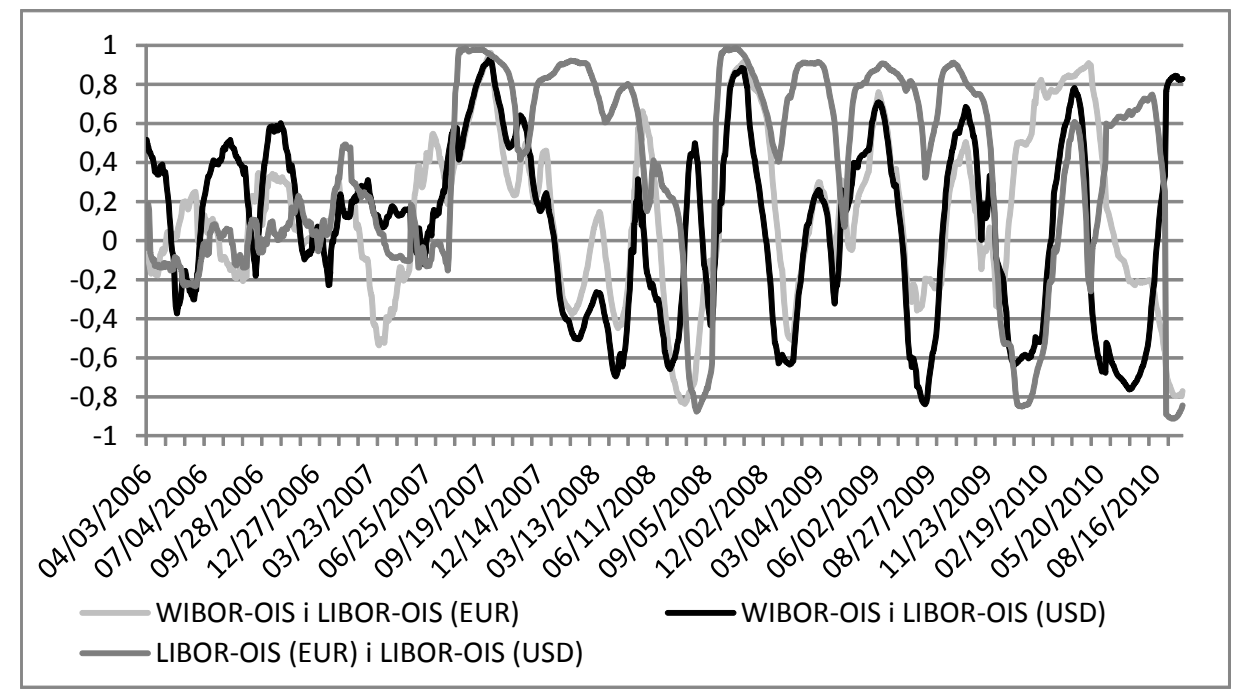

Rysunek 2. Korelacja 3-miesięcznych spreadów LIBOR-OIS dla złotego, euro i dolara amerykańskiego

Źródło: opracowanie własne.

Przez następnych kilka miesięcy spread dla dolara stopniowo wzrasta, co wiąże się bezpośrednio ze spadającym zaufaniem na rynku międzybankowym w Stanach Zjednoczonych (por. Heider i in., 2008). W tym samym czasie spread dla strefy euro stopniowo wygasa po szokach związanych z kłopotami 
banków, po czym stabilizuje się na wysokim poziomie około 65 pb. Sytuacja ulega gwałtownej zmianie w momencie upadku banku Lehman Brothers 15 września 2008 roku. Wydarzenie to przekłada się na krótkofalowy wzrost spreadów o ponad 2,5 p.p. Tak ogromny spadek zaufania na rynkach międzybankowych wiązał się z faktem, że o ile dotychczas zagrożone instytucje finansowe wychodziły z problemów obronną ręka, to teraz nie uchroniono przed upadkiem czwartego co do wielkości banku inwestycyjnego w Stanach Zjednoczonych. Co ciekawe, o ile wcześniej spread dla Polski nie zareagował na dwa sygnały z rynków zagranicznych, to upadek Lehman Brothers przełożył się na wzrost spreadu o około 1,5 p.p. ${ }^{2}$ Wzrost ten nie jest co prawda tak duży jak w przypadku spreadów dla dolara amerykańskiego i euro, ale jego skutki będą bardziej długofalowe. Wzrost spreadów dla dolara i euro zostaje zniwelowany już na początku października 2008 roku przez wprowadzenie planu Paulsona, który ma za zadanie oczyścić banki z obciążających ich bilanse „złych aktywów - długów udzielanych klientom, dla których prawdopodobieństwo niewypłacalności jest duże". Na realizację planu przeznaczono 700 mld dolarów. Po wprowadzeniu planu Paulsona spready dla dolara amerykańskiego i euro zaczynają maleć, stabilizując się na poziomie 15-35 b.p. W tym samym czasie spread dla Polski utrzymuje się na poziomie zbliżonym do 1,5 p.p., do maja 2009 roku zachowując bardzo wysoką zmienność, po czym zaczyna maleć począwszy od lutego 2010. Pod koniec badanego okresu, po fali długoterminowych spadków, obserwujemy ponowny wzrost spreadów dla dolara amerykańskiego i euro po tym, jak 23 kwietnia grecki rząd występuje z oficjalną prośbą do Unii Europejskiej i Międzynarodowego Funduszu Walutowego o uruchomienie mechanizmu pomocy dla Grecji. Przyznanie pomocy Grecji wyhamowuje wzrost spreadu dla euro, natomiast spread dla dolara amerykańskiego jeszcze jakiś czas wzrasta (więcej na temat reakcji rynku międzybankowego w Stanach Zjednoczonych na kłopoty Grecji można znaleźć w artykule Taylora (2010)).

Ze względu na charakterystykę szeregów badana próba została podzielona na dwie części: pierwszą przedkryzysową od 3 stycznia 2006 do 8 sierpnia 2007 roku i drugą od 9 sierpnia 2007 do 24 września 2010 roku, obejmującą już okres kryzysu. Jak wskazują Taylor i Williams (2008), właśnie 9 sierpnia 2007 roku efektywna stopa rezerw federalnych wzrosła do nadzwyczajnie wysokiego poziomu, by w kolejnym dniu zmniejszyć wartość o blisko jeden procent po tym, jak FED zasilił rynek w płynność. Gwałtowny wzrost zmienności okazał się trwały, co zostało zinterpretowane przez Taylora i Williamsa

\footnotetext{
${ }^{2}$ Wzrost ten wiązał się jednocześnie $\mathrm{z}$ upublicznieniem informacji o kondycji finansowej banków będących udziałowcami banków działających w Polsce.
} 
(2008) jako pojawienie się na rynku kryzysu zaufania. Szerszą dyskusję na temat wydarzeń z 9 i 10 sierpnia 2008 roku i ich wpływu na rozwój kryzysu można znaleźć w pracy Cecchettiego (2008). Jednocześnie warto zwrócić uwagę, że skupiska zmienności we wszystkich badanych spreadach się nie pokrywają. Jak pokazuja badania przeprowadzone przez Franka i Hesse (2009), zmienność spreadu LIBOR-OIS jest w znacznym stopniu uzależniona od zmiennych związanych z polityką pieniężna, która - jak wiadomo - dla każdego z badanych rynków jest prowadzona niezależnie. Statystyki opisowe spreadów $\mathrm{w}$ badanych podokresach przedstawione są $\mathrm{w}$ tabeli 1 , a wartości korelacji pomiędzy spreadami zaprezentowaliśmy $\mathrm{w}$ tabeli 2. Aby uzyskać bardziej precyzyjną informację na temat zmieniającej się w czasie korelacji, na rysunku 1 przedstawiliśmy także korelacje spreadów wyznaczone na podstawie miesięcznego okna.

Tabela 1. Statystyki opisowe przyrostów 3-miesięcznych spreadów LIBOR-OIS dla złotego, euro i dolara amerykańskiego

\begin{tabular}{|l|c|c|c|c|c|c|}
\hline \multirow{2}{*}{$\begin{array}{c}\text { Statystyka } \\
\text { opisowa }\end{array}$} & \multicolumn{2}{|c|}{ Przed kryzysem (02.01.2006-08.08.2007) } & \multicolumn{2}{|c|}{ W trakcie kryzysu (09.08.2007-24.09.2010) } \\
\cline { 2 - 7 } & $\begin{array}{c}\text { WIBOR 3M- } \\
\text { OIS }\end{array}$ & $\begin{array}{c}\text { EUR LIBOR } \\
\text { 3M-OIS }\end{array}$ & $\begin{array}{c}\text { USD LIBOR } \\
\text { 3M-OIS }\end{array}$ & $\begin{array}{c}\text { WIBOR 3M- } \\
\text { OIS }\end{array}$ & $\begin{array}{c}\text { EUR LIBOR } \\
\text { 3M-OIS }\end{array}$ & $\begin{array}{c}\text { USD LIBOR } \\
\text { 3M-OIS }\end{array}$ \\
\hline Średnia & 0,0006 & 0,0003 & 0,0006 & $-0,0004$ & $-0,0002$ & $-0,0004$ \\
Odch. std. & 0,0137 & 0,0098 & 0,0132 & 0,1189 & 0,0467 & 0,0570 \\
Skośność & 0,9629 & 1,2402 & 4,8951 & $-1,0360$ & 0,1852 & 0,9334 \\
Kurtoza & 20,7112 & 21,7460 & 93,7327 & 31,4515 & 97,3791 & 34,0066 \\
Minimum & $-0,0800$ & 0,0651 & $-0,1180$ & $-1,0600$ & 0,6404 & $-0,5367$ \\
Maksimum & 0,1200 & 0,0724 & 0,1675 & 0,9300 & 0,6399 & 0,5558 \\
\hline
\end{tabular}

Źródło: opracowanie własne.

Tabela 2. Korelacje bezwarunkowe 3-miesięcznych spreadów LIBOR-OIS dla złotego, euro i dolara amerykańskiego.

\begin{tabular}{|l|c|c|c|c|c|c|}
\hline \multirow{2}{*}{$\begin{array}{c}\text { Szereg } \\
\text { Czasowy }\end{array}$} & \multicolumn{2}{|c|}{ Przed kryzysem (02.01.2006-08.08.2007) } & \multicolumn{3}{|c|}{ W trakcie kryzysu (09.08.2007-24.09.2010) } \\
\cline { 2 - 7 } & $\begin{array}{c}\text { WIBOR 3M- } \\
\text { OIS }\end{array}$ & $\begin{array}{c}\text { EUR LIBOR } \\
\text { 3M-OIS }\end{array}$ & $\begin{array}{c}\text { USD LIBOR } \\
\text { 3M-OIS }\end{array}$ & $\begin{array}{c}\text { WIBOR 3M- } \\
\text { OIS }\end{array}$ & $\begin{array}{c}\text { EUR LIBOR } \\
\text { 3M-OIS }\end{array}$ & $\begin{array}{c}\text { USD LIBOR } \\
\text { 3M-OIS }\end{array}$ \\
\hline $\begin{array}{l}\text { WIBOR 3M- } \\
\text { OIS }\end{array}$ & 1 & 1 & & 1 & & \\
\hline $\begin{array}{l}\text { EUR LIBOR } \\
\text { 3M-OIS }\end{array}$ & $-0,0595$ & 1 & $-0,1385$ & 0,9236 & 1 \\
\hline $\begin{array}{l}\text { USD LIBOR } \\
\text { 3M-OIS }\end{array}$ & 0,3088 & 0,2389 & 1 & & & \\
\hline
\end{tabular}

Źródło: opracowanie własne. 
W tabeli 1 obserwujemy znaczący wzrost zmienności wszystkich spreadów po wybuchu kryzysu zaufania. Godna uwagi jest też ogromna kurtoza przyrostów spreadów, która jest efektem tego, że reagują one na liczne informacje napływające $\mathrm{z}$ rodzimych i zagranicznych rynków finansowych oraz na decyzje banków centralnych. Kurtoza w obliczu kryzysu także wzrasta. Tabela 2 potwierdza słabą korelację spreadu dla polskiego złotego ze spreadem dla dolara i praktycznie jej brak dla spreadu dla złotego i euro przed wybuchem kryzysu. Wraz z wybuchem kryzysu korelacja pomiędzy spreadami dla dolara i euro staje się bardzo silna (na rysunku 2 widzimy, że przez znaczącą część okresu przyjmuje ona wartość zbliżoną do 1), podczas gdy korelacja pomiędzy spreadami dla euro i złotego oraz dolara i złotego przez znaczącą część okresu jest ujemna, co świadczy o częstym występowaniu przeciwnych kierunków zmian wartości spreadów dla złotego oraz pozostałych badanych walut. $\mathrm{Na}$ tej podstawie wnioskujemy, że spread WIBOR-OIS kształtuje się niezależenie od spreadów LIBOR-OIS dla euro i dolara amerykańskiego, co przemawia za prawdziwością pierwszej z postawionych $\mathrm{w}$ artykule hipotez. Ostatecznej jej weryfikacji dokonamy jednak, opierając się na opisanych w kolejnym rozdziale badaniach.

W czerwcu 2012 roku brytyjski bank Barclays został ukarany grzywną 290 milionów funtów za manipulowanie stopami procentowymi rynku międzybankowego. W tym kontekście mogą rodzić się zastrzeżenia do badań dokonywanych na spreadzie LIBOR-OIS. Doniesienia o możliwym zaniżaniu stopy LIBOR przez banki napływały do British Bankers Association już w 2007 roku. Niejednokrotnie krytykowano też samą procedurę wyznaczania stóp LIBOR. Nie wpłynęło to jednak na powszechne wykorzystanie spreadów LIBOR-OIS, które po dziś dzień uważane są za najlepszy miernik awersji do ryzyka na rynku międzybankowym. Jeśli dodatkowo weźmiemy pod uwagę, że bank Barclays do listopada 2008 roku podawał najwyższe kwotowania stóp LIBOR, a więc jego oferty były odrzucane, zmniejszając je później do poziomu zbliżonego do średniej, incydent ten nie mógł w znacznym stopniu wpłynąć na wartość spreadów i ich charakterystykę.

\section{BADANIE}

Przeprowadzone badanie ma na celu identyfikację zależności występujących pomiędzy spreadami. Ponieważ rozszerzony test Dickeya-Fullera (Said, Dickey, 1984) nie pozwolił na odrzucenie hipotezy zerowej o obecności pierwiastka jednostkowego we wszystkich spreadach, modelowaniu poddane zostały ich przyrosty. W celu określenia wzajemnych zależności pomiędzy przy- 
rostami spreadów estymujemy wektorowy model autoregresji (VAR), który w ogólności przyjmuje następującą postać:

$$
r_{t}=a_{0}+\mathrm{A}_{1} r_{t-1}+\ldots+\mathrm{A}_{p} r_{t-p}+\varepsilon_{t},
$$

gdzie $a_{0}$ jest $k$-wymiarowym wektorem, $\mathrm{A}_{i}$ są macierzami wymiaru $k \times k$, a $\left.\varepsilon_{t}=\varepsilon_{1 t}, \ldots, \varepsilon_{k t}\right)^{\prime}$ jest $k$-wymiarowym białym szumem $\mathrm{z}$ macierzą kowariancji $\Sigma$. Rząd modelu został dobrany na podstawie kryterium informacyjnego Akaike'a.

Celem określenia wpływu, jakie wywierają na siebie nawzajem spready LIBOR-OIS, na podstawie dopasowanych modeli VAR wyznaczamy funkcje odpowiedzi na impuls. Przeprowadzamy także testy przyczynowości w sensie Grangera (1969), wykorzystując w tym celu popularną statystykę Walda z rozkładem $F$ Snedecora (por. Lütkepohl, 2005, s. 41-50).

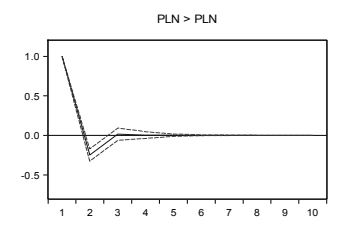

PLN > EUR

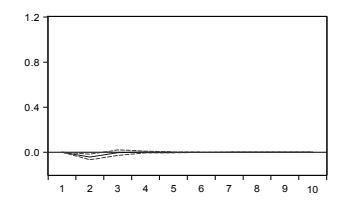

PLN > USD

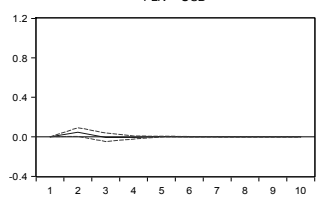

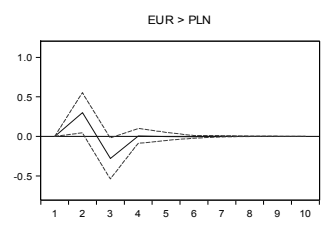

EUR $>$ EUR

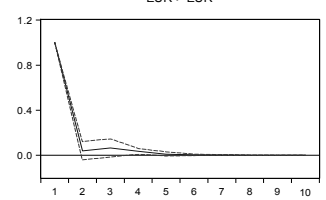

EUR $>$ USD

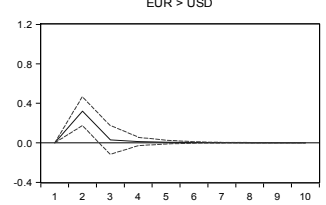

USD > PLN

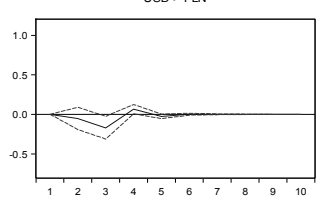

USD > EUR

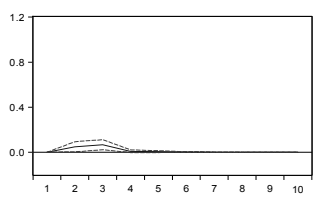

USD > USD

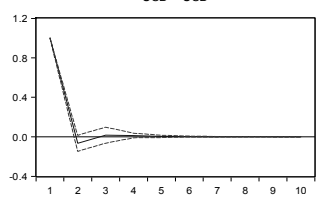

Rysunek 3. Odpowiedź na jednostkowe zaburzenie spreadów wraz z pasmem \pm 2 odchyleń standardowych dla poszczególnych walut z okresu 02.01.2006-08.08 .2007 (Model VAR (2))

Źródło: opracowanie własne.

Przedstawione na rysunkach 3 i 4 wykresy odpowiedzi na impuls sugeruja, że zarówno przed kryzysem, jak i w trakcie jego trwania spread dla złotego reagował w sposób istotny na zaburzenia spreadu dla euro. Jednostkowe zaburzenie spreadu dla dolara amerykańskiego generuje niewielkie ujemne zaburzenie spreadu dla złotego. Jego bezwzględna wartość nie przekracza jednak 


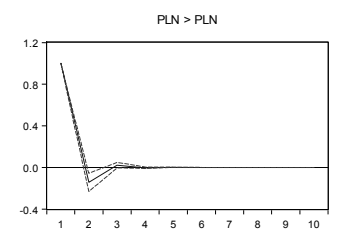

$\mathrm{PLN}>\mathrm{EUR}$

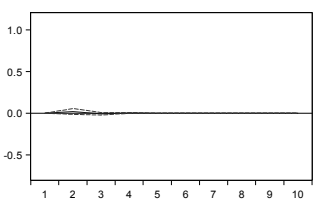

$\mathrm{PLN}>\mathrm{USD}$

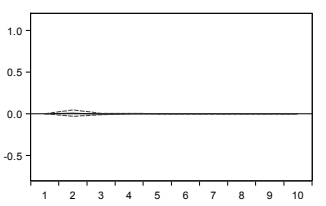

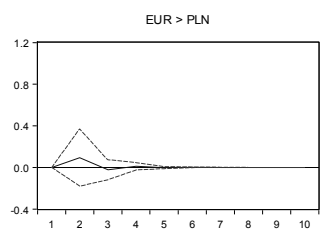

EUR > EUR

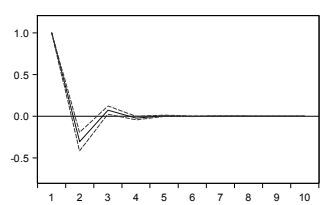

EUR $>$ USD

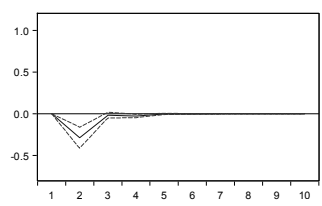

$\cos >\sin$

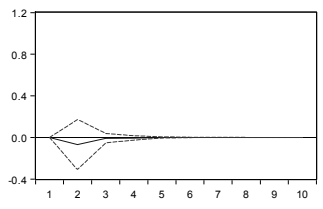

USD > EUR

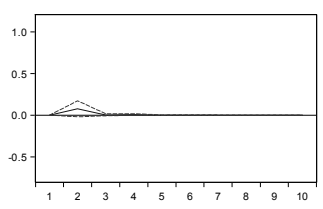

USD > USD

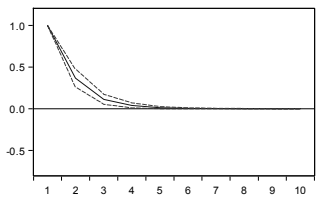

Rysunek 4. Odpowiedź na jednostkowe zaburzenie spreadów wraz z pasmem \pm 2 odchyleń standardowych dla poszczególnych walut $\mathrm{z}$ okresu 09.08.2007-24.09.2010 (Model VAR (1))

Źródło: opracowanie własne.

Tabela 3. Testy przyczynowości w sensie Grangera dla przyrostów spreadów

\begin{tabular}{|c|c|c|}
\hline Zależność & $\begin{array}{c}\text { Przed kryzysem (02.01.2006-08.08.2007) } \\
\text { model VAR(2) }\end{array}$ & $\begin{array}{c}\text { W trakcie kryzysu }(09.08 .2007-24.09 .2010) \\
\text { model VAR(1) }\end{array}$ \\
\hline $\mathrm{PLN} \rightarrow$ EUR & $1,3902(0,2502)$ & $0,3267 \quad(0,5678)$ \\
\hline EUR $\rightarrow$ PLN & $0,2500(0,7789)$ & $0,5804(0,4464)$ \\
\hline $\mathrm{PLN} \rightarrow$ USD & $0,0076(0,9925)$ & $0,6414(0,4235)$ \\
\hline $\mathrm{USD} \rightarrow \mathrm{PLN}$ & $0,0579(0,9438)$ & $0,0733(0,7867)$ \\
\hline $\mathrm{EUR} \rightarrow \mathrm{USD}$ & $2,0441(0,1309)$ & $7,4840(0,0064){ }^{* * *}$ \\
\hline USD $\rightarrow$ EUR & $0,0156(0,9846)$ & $2,6516(0,1038)$ \\
\hline
\end{tabular}

Symbol *** oznacza odrzucenie $\mathrm{H}_{0}$ na poziomie istotności $1 \%$.

Źródło: opracowanie własne.

pasma dwóch odchyleń standardowych, wobec czego możemy przyjąć, że reakcja ta jest statystycznie nieistotna. Zgodnie z oczekiwaniami nieistotne są również reakcje spreadów dla euro i dolara na jednostkowe zaburzenia spreadu dla złotego. Co ciekawe, spread dla dolara amerykańskiego reaguje znacznie silniej na zaburzenia spreadu dla euro niż odwrotnie. Testy przyczynowości w sensie Grangera (tabela 3) wykazały, że przed wybuchem kryzysu zaufania 
pomiędzy spreadami nie istniały także zależności przyczynowe. Po wybuchu kryzysu zaufania możemy jedynie zaobserwować, że spread dla dolara amerykańskiego stał się przyczyną w sensie Grangera spreadu dla euro. Na podstawie przeprowadzonej analizy wnioskujemy, że spread dla Polski kształtuje się w sposób niezależny. Nie tylko jest słabo skorelowany z pozostałymi spreadami, ale także nie jest on przyczyną w sensie Grangera innych spreadów, a ponadto w sposób istotny reaguje jedynie na zaburzenia spreadu dla euro.

Celem identyfikacji warunkowej heteroskedaktyczności dla wszystkich rozważanych spreadów przeprowadziliśmy test Engle'a (1982). O ile w przypadku pierwszego rozważanego podokresu test nie dał podstaw do odrzucenia warunkowej homoskedaktyczności dla szeregu przyrostów spreadu dla złotego, to już w drugim ze względu na pojawiające się okresowe wzrosty zmienności pojawił się efekt ARCH we wszystkich rozważanych szeregach. Test Engle'a-Shepparda (2001) dodatkowo wskazał na zmienną w czasie korelację warunkową $\mathrm{w}$ drugim podokresie. Wobec tego do opisu przyrostów spreadu w drugim podokresie ostatecznie wykorzystamy model $\operatorname{VAR}(1)-\operatorname{DCC}(1,1)$ (Engle, 2002) z wariancją warunkową poszczególnych przyrostów spreadów opisaną za pomocą modelu IGARCH. Ze względu na obecność silnej leptokurtozy w rozważanych szeregach postanowiliśmy wykorzystać rozkład innowacji $t$ Studenta. Macierz warunkowej kowariancji w modelu DCC opisana została w następujący sposób:

$$
\begin{aligned}
& H_{t}=D_{t} R_{t} D_{t} \\
& D_{t}=\operatorname{diag}\left(\sqrt{h_{11, t}}, \ldots ., \sqrt{h_{k k, t}}\right) \\
& h_{i i, t}=\omega_{i}+\alpha_{1 i} y_{i, t-1}^{2}+\beta_{1 i} h_{i i, t-1}^{2} \text { dla i }=1,2, \ldots, k \\
& R_{t}=\left(\operatorname{diag}\left(Q_{t}\right)\right)^{-1 / 2} Q_{t}\left(\operatorname{diag}\left(Q_{t}\right)\right)^{-1 / 2} \\
& Q_{t}=\left(1-\sum_{m=1}^{M} \alpha_{m}+\sum_{n=1}^{N} \beta_{n}\right) \bar{Q}+\sum_{m=1}^{M} \alpha_{m} u_{t-m}\left(u_{t-m}\right)^{\prime}+\sum_{n=1}^{N} \beta_{n} Q_{t-n},
\end{aligned}
$$

gdzie $y_{t}$ jest wektorem reszt w momencie $t \mathrm{z}$ modelu liniowego, a $u_{t}$ wektorem reszt standaryzowanych. Przez $Q_{t}$ oznaczyliśmy symetryczną, dodatnio określoną macierz stopnia $k$, a macierz $\bar{Q}$ jest bezwarunkową macierzą kowariancji reszt standaryzowanych. Ponadto parametry modelu muszą spełniać warunek:

$$
\sum_{m=1}^{M} \alpha_{m}+\sum_{n=1}^{N} \beta_{n}<1
$$

Oszacowania parametrów modelu warunkowej korelacji $\operatorname{VAR}(1)-\operatorname{DCC}(1,1)$ przedstawione są w tabeli 4 . Do estymacji modelu zastosowano metodę jednokrokowa. 
Tabela 4. Oszacowanie parametrów modelu $\operatorname{VAR}(1)-\mathrm{DCC}(1,1)$ dla przyrostów spreadów LIBOR-OIS dla polskiego złotego, euro oraz dolara amerykańskiego

\begin{tabular}{|c|c|c|c|l|}
\hline Parametr & Oszacowanie & Błąd standardowy & $t$ statystyka & $p$-wartość \\
\hline $\mathrm{a}_{1,11}$ & $-0,1711$ & 0,0350 & $-4,8770$ & $0^{* * *}$ \\
$\mathrm{a}_{1,12}$ & 0,2381 & 0,1360 & 1,7510 & $0,0803^{*}$ \\
$\mathrm{a}_{1,13}$ & $-0,0569$ & 0,0879 & $-0,6475$ & 0,5175 \\
$\mathrm{a}_{1,21}$ & $-0,0032$ & 0,0098 & $-0,3218$ & 0,7477 \\
$\mathrm{a}_{1,22}$ & 0,0302 & 0,0380 & 0,7949 & 0,4269 \\
$\mathrm{a}_{1,23}$ & 0,0929 & 0,0245 & 3,7840 & $0,0002^{* * *}$ \\
$\mathrm{a}_{1,31}$ & 0,0033 & 0,0140 & 0,2372 & 0,8125 \\
$\mathrm{a}_{1,32}$ & 0,3019 & 0,0543 & 5,5570 & $0^{* * *}$ \\
$\mathrm{a}_{1,33}$ & 0,2886 & 0,0351 & 8,2130 & $0^{* * *}$ \\
$\mathrm{a}_{11}$ & 0,1434 & 0,0435 & 3,2970 & $0,001^{* * *}$ \\
$\beta_{11}$ & 0,8566 & - & - & - \\
$\mathrm{a}_{21}$ & 0,1243 & 0,0173 & 7,1670 & $0^{* * *}$ \\
$\beta_{21}$ & 0,7857 & - & - & - \\
$\mathrm{a}_{31}$ & 0,1641 & 0,0341 & 4,8160 & $0^{* * *}$ \\
$\beta_{31}$ & 0,8351 & - & - & - \\
$\mathrm{q}_{21}$ & 0,0254 & 0,0356 & 0,7145 & 0,4751 \\
$\mathrm{q}_{31}$ & 0,0193 & 0,0300 & 0,6430 & 0,5204 \\
$\mathrm{q}_{32}$ & 0,1323 & 0,0353 & 3,7430 & $0,0002^{* * *}$ \\
$\mathrm{a}_{1}$ & 0,0067 & 0,0032 & 2,0560 & $0,0401^{* *}$ \\
$\beta_{1}$ & 0,9153 & 0,0200 & 45,8600 & 0 \\
$\mathrm{df}$ & 4,1016 & 0,2555 & - & - \\
\hline
\end{tabular}

Symbole $*, * *, * * *$ oznaczają odrzucenie $\mathrm{H}_{0}$ odpowiednio na poziomie istotności $10 \%, 5 \%$ i 1\%. Źródło: opracowanie własne.

Brak istotności oszacowań parametrów $q_{21}$ oraz $q_{31}$ odpowiedzialnych za korelację bezwarunkową reszt standaryzowanych wiąże się pośrednio $\mathrm{z}$ brakiem korelacji bezwarunkowej pomiędzy spreadem dla Polski i każdym z pozostałych dwóch spreadów. Oszacowanie parametru $d f$ tylko nieznacznie przekraczające 4 wynika ze wspomnianej dużej kurtozy przyrostów spreadów. Na poniższym rysunku 5 przedstawiona jest warunkowa korelacja otrzymana za pomocą modelu (1).

Wykresy korelacji warunkowej tylko potwierdzają hipotezę o bardzo małej korelacji spreadu dla złotego z pozostałymi spreadami. Korelacja warunkowa dla spreadów dla dolara amerykańskiego i euro pozostaje znacznie wyższa, utrzymując się na poziomie zbliżonym do 0,2 . Jej pierwszy niewielki wzrost wiąże się $\mathrm{z}$ nacjonalizacją banku Northern Rock, kolejny - znacznie większy - przypada na upadek banku Lehman Brothers. Ostatni i największy wzrost związany jest z wystapieniem Grecji o uruchomienie pakietu pomocowego. 


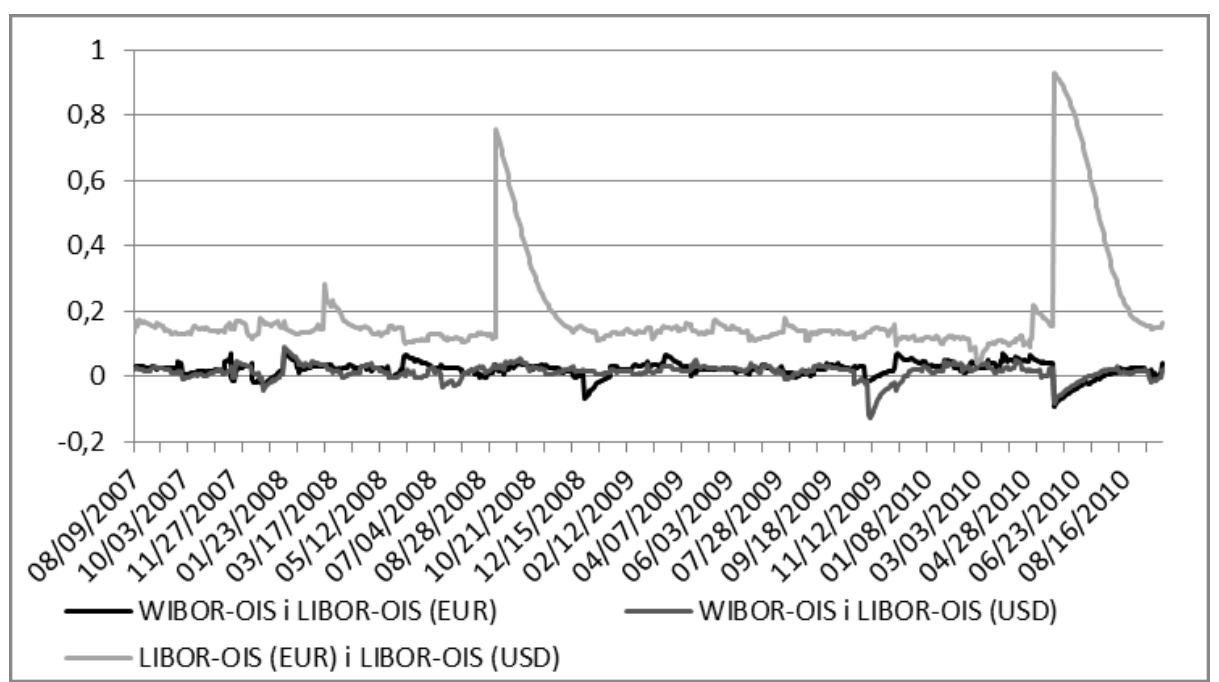

Rysunek 5. Korelacja warunkowa pomiędzy spreadami WIBOR-OIS LIBOR-OIS dla dolara amerykańskiego i euro w okresie 09.08.2007-24.09.2010 wyznaczona na podstawie modelu 1

Źródło: opracowanie własne.

Tabela 5. Wartości statystyki ( $p$-wartości) testu Cheunga i Ng przeprowadzonego dla wariancji spreadów LIBOR-OIS dla polskiego złotego, euro i dolara amerykańskiego

\begin{tabular}{|c|c|c|c|c|c|c|}
\hline Opóźnienie & PLN $\rightarrow$ EUR & EUR $\rightarrow$ PLN & PLN $\rightarrow$ USD & USD $\rightarrow$ PLN & EUR $\rightarrow$ USD & USD $\rightarrow$ EUR \\
\hline \multirow{2}{*}{1} & 0,0053 & 0,0152 & 0,0022 & 0,0067 & 0,4399 & 0,0228 \\
& $(0,9418)$ & $(0,9019)$ & $(0,9629)$ & $(0,9350)$ & $(0,5072)$ & $(0,88)$ \\
\hline \multirow{2}{*}{2} & 0,0156 & 0,0337 & 0,0022 & 0,0334 & 0,4429 & 0,0293 \\
& $(0,9922)$ & $(0,9832)$ & $(0,9989)$ & $(0,9834)$ & $(0,8014)$ & $(0,9854)$ \\
\hline \multirow{2}{*}{5} & 0,1174 & 0,0533 & 0,0531 & 0,0654 & 0,4759 & 0,1206 \\
& $(0,9998)$ & $(0,9999)$ & $(0,9999)$ & $(0,9999)$ & $(0,9930)$ & $(0,9997)$ \\
\hline \multirow{2}{*}{10} & 0,4744 & 1,3528 & 0,6117 & 0,2503 & 0,5530 & 0,1660 \\
& $(0,9999)$ & $(0,9993)$ & $(0,9999)$ & $(0,9999)$ & $(0,9999)$ & $(0,9999)$ \\
\hline \multirow{2}{*}{15} & 0,4912 & 1,4216 & 0,4912 & 0,3280 & 0,6231 & 0,2444 \\
& $(0,9999)$ & $(0,9999)$ & $(0,9999)$ & $(0,9999)$ & $(0,9999)$ & $(0,9999)$ \\
\hline \multirow{2}{*}{20} & 0,5555 & 1,4609 & 0,5555 & 0,3755 & 0,6755 & 0,8713 \\
& $(0,9999)$ & $(0,9999)$ & $(0,9999)$ & $(0,9999)$ & $(0,9999)$ & $(0,9999)$ \\
\hline
\end{tabular}

Źródło: opracowanie własne.

Obecność warunkowej heteroskedaktyczności we wszystkich szeregach $\mathrm{z}$ drugiego badanego podokresu pozwoliło nam na przeprowadzenie testu 
Cheunga i Ng (1996) przyczynowości w wariancji, którego wyniki przedstawione są w tabeli 5 . Wyniki testu wskazały jednoznacznie, że w wariancji nie występują żadne zależności przyczynowe, co potwierdza wcześniejsze wnioski postawione na podstawie rysunku 1 .

\section{PODSUMOWANIE}

W artykule wykazaliśmy, że kryzys zaufania, który ogarnął rynki międzybankowe większości krajów wysokorozwiniętych, ukształtował się w Polsce niezależnie od kryzysu w Stanach Zjednoczonych i strefie euro. Taki stan rzeczy należy do bardzo nietypowych. Dla porównania badania przeprowadzone przez Soultanaevę i Strömqvist (2009) dla rynku szwedzkiego wskazały, że kryzys zaufania przenika do Szwecji bezpośrednio ze Stanów Zjednoczonych w podobnym stopniu jak do strefy euro. Biorąc pod uwagę specyfikę polskiego rynku, która została pokrótce nakreślona w rozdziale pierwszym, brak zależności rynku polskiego od innych rynków wydaje się zrozumiały i tym samym pozytywnie weryfikuje pierwszą postawioną $\mathrm{w}$ pracy hipotezę. Wielowymiarowe modele średniej i zmienności warunkowej pozwalają identyfikować zależności krótkookresowe, dlatego nie udało nam się zweryfikować drugiej postawionej w pracy hipotezy. Nie możemy jej odrzucać, chociaż modele ekonometryczne nie pozwoliły zidentyfikować zależności pomiędzy spreadem dla Polski i strefy euro. Wykorzystane modele pokazały jedynie, że nie ma zależności krótkookresowych pomiędzy jednym a drugim rynkiem. Ze względu na swoją konstrukcję nie są w stanie zweryfikować zależności długookresowych. Trzeba zwrócić uwagę, że polski rynek finansowy jest cały czas słabo rozwinięty (stosunek kapitalizacji GPW do produktu krajowego brutto Polski jest znacznie mniejszy niż w przypadku krajów wysokorozwiniętych). Podstawowym kanałem współpracy gospodarczej jest więc wymiana handlowa, a - jak wiadomo - głównymi partnerami handlowymi Polski są państwa strefy euro.

Nasze badanie pokazało dodatkowo, że powiązanie pomiędzy nasileniem kryzysu zaufania w strefie euro i Stanach Zjednoczonych jest bardzo znaczące, a impulsy pomiędzy spreadami LIBOR-OIS przepływają w obydwu kierunkach. $Z$ jednej strony banki w strefie euro silnie zareagowały na kryzys subprime, jako że same były często posiadaczami niskiej jakości papierów powiązanych $\mathrm{z}$ rynkiem nieruchomości. $Z$ drugiej strony rynek międzybankowy w Stanach Zjednoczonych nerwowo zareagował na kłopoty fiskalne Grecji, mimo że amerykańskie instytucje finansowe posiadały niewielki procent greckich papierów skarbowych. Znaczące powiązanie banków amerykańskich z in- 
stytucjami europejskimi, a także perspektywa kłopotów fiskalnych kolejnych państw europejskich spowodowały, że reakcja na informacje o problemach Grecji była tak silna. Warto zwrócić uwagę, że badania przeprowadzone przez European Central Bank (2008) pokazały, że kierunek przepływu impulsów był jeden - ze Stanów Zjednoczonych do strefy euro. Trzeba jednak wziąć pod uwagę, że rozważana w wyżej wymienionej pozycji próba była znacznie krótsza i nie obejmowała okresu, w którym z Europy zaczęły nadchodzić niepokojące sygnały związane z kryzysem fiskalnym niektórych państw strefy euro.

\section{LITERATURA}

Bank of Japan (2008), Cross-currency transmission of money market tensions, „Bank of Japan Review", July, 1-11.

Cecchetti S. G. (2008), Monetary Policy and the Financial Crisis of 2007-2008, CEPR Policy Insight No. 21.

Cheung Y. W., Ng L. K. (1996), A causality-in-variance test and its application to financial market prices, ,Journal of Econometrics”, 72, 33-48.

European Central Bank (2008), Financial Stability Review, Box 3 Transmission of US dollar and pound sterling money market tensions to EUR money markets, December, 29-30.

Engle R. F. (1982), Autoregressive Conditional Heteroscedasticity with Estimates of the Variance of United Kingdom Inflation, „Econometrica”, 50, 987-1007.

Engle R. F. (2002), Dynamic Conditional Correlation - a Simple Class of Multivariate GARCH Models, ,Journal of Business and Economic Statistics”, 20, 339-350.

Engle R. F., Sheppard K. (2001), Theoretical and Empirical properties of Dynamic Conditional Correlation Multivariate GARCH, Mimeo, UCSD.

Frank N., Hesse H., (2009) The Effectiveness of Central Bank Interventions During the First Phase of the Subprime Crisis, Working Paper of International Monetary Fund 09/206

Gibson H. D., Hall S. G., Tavlas G. S., The Greek Financial Crisis: Growing Imbalances and Sovereign Spreads, Bank Of Greece Working Paper 124.

Granger C. W. J. (1969), Investigating Causal Relations by Econometric Models and Cross-Spectral Methods, ,Econometrica”, 37, 424-438.

Heider F., Hoerova M., Holthausen C. (2008), Liquidity hoarding and interbank market spreads: The role of counterparty risk, Working Paper ECB, November.

In F. H., Cui J., Mahraj A. (2008), The Impact of a New Term Auction Facility on LIBOR-OIS Spreads and Volatility Transmission between Money and Mortgage Markets During the Subprime Crisis, SSRN Working Paper.

Lütkepohl H. (2005), New Introduction to Multiple Time Series Analysis, Springer Verlag, Berlin Heidelberg.

Narodowy Bank Polski (2009), Polska wobec światowego kryzysu gospodarczego, Warszawa. 
Said E., Dickey D. A. (1984), Testing for Unit Roots in Autoregressive Moving Average Models of Unknown Order, „Biometrika”, 71, 599-607.

Schwert G. M. (1989), Why Does Stock Market Volatility Change Over Time, „The Journal of Finance", 54 (5), 1115-1143.

Sengupta R., Yu M. T. (2008), The LIBOR-OIS Spread as a Summary Indicator, „Economic Synopses", 25, Federal Reserve Bank of St. Louis.

Soultanaeva A., Strömqvist M. (2009), The Swedish Money Market Risk Premium Experiences from the Crisis, „Economic Review”, 3.

Taylor J. B. (2010), The Fed's Swap Loans and Libor-OIS Spread, http://wallstreetpit.com, pobrano 13.08.2011.

Taylor J. B., Williams J. C. (2008), Further Results on a Black Swan in the Money Market, NBER Working Paper No. 13943, April.

Thorton D. L. (2009), What the Libor-OIS Spread Says, „Economic Synopses”, 24, Federal Reserve Bank of St. Louis.

Wu T. (2008), On the Effectiveness of the Federal Reserve's New Liquidity Facilities, Federal Reserve Bank of Dallas, April.

\section{THE TRANSMISSION OF THE CRISIS OF CONFIDENCE TO THE POLISH INTERBANK MARKET}

A b s t r a c t . The former U. S. Federal Reserve Board of Governors Alan Greenspan stated recently that the LIBOR-OIS spread, understood as the difference between the LIBOR rate and the term overnight indexed swap, is ,a barometer of fears of bank insolvency". In the following article we use the LIBOR-OIS spreads in Polish zloty, American dollar and euro to determine the moment of transmission of the crisis of confidence to considered interbank markets and the directions of crisis transmission. Our analysis is based on the results obtained from the multivariate parametric models. Basing on the analysis we show strong dependence between the euro zone and the USA markets as well as independence of the Polish markets from the other ones.

K e y w o r d s : conditional correlation, impulse response function, Granger causality, LIBOR-OIS spread. 